\title{
The Vomeronasal Organ: A Neglected Organ
}

\author{
Biagio D'Aniello ${ }^{1}$, Gün R. Semin ${ }^{2}$, Anna Scandurra ${ }^{1}$ and Claudia Pinelli ${ }^{3 *}$ \\ ${ }^{1}$ Department of Biology, University of Naples "Federico II," Naples, Italy, ${ }^{2}$ William James Center for Research, Instituto \\ Superior de Psicologia Aplicada - Instituto Universitário (ISPA-IU), Lisbon, Portugal, ${ }^{3}$ Department of Environmental, Biological \\ and Pharmaceutical Sciences and Technologies, University of Campania "L. Vanvitelli," Caserta, Italy
}

Keywords: olfaction, human VNO, VNO homolog, vertebrate VNO, vomeronasal organ

Even though the vomeronasal organ, part of the accessory olfactory system (AOS), has been extensively studied in vertebrates, a lot remains to be understood on its function (see Spehr et al., 2006). The problematic nature of our understanding of this structure does not only relate to its function, but also partly to its presence/absence in vertebrates. A recent article in "Science" (McGann, 2017) has denied the presence of the VNO in humans. It is ironic that the first indication of a VNO was in humans and only at a later stage in other mammals. Ruysch, a seventeenth to eighteenth century Dutch anatomist, was the first to mention an organ near the nasal septum of a human infant (Ruysch, 1703, 1724). However, the discovery of the human VNO was ascribed to Kölliker (1877) as Ruysch did not supply an accurate description or provide a name and according to Bhatnagar and Smith (2003) he described a "nasal canal," too close to the palate to represent the VNO. Thus, it was Kölliker (1877), who among eighteenth to nineteenth century investigators became known as the first to provide evidence of the human VNO as a histologically identifiable structure. Indeed, he identified this structure in both the fetus and the adult human brain. Jacobson (1811) studied the VNO intensively across a variety of mammals, although he denied its existence in humans. Consequently, VNO is now also known as "Jacobson's organ," largely due to Potiquet (1891), who supplied the first extensive discussion of the VNO in humans.

In primates, the VNOs have extremely variable features (Smith et al., 2001). In human embryos,

OPEN ACCESS

Edited by:

Zoltan F. Kisvarday,

University of Debrecen, Hungary

Reviewed by:

Mario F. Wullimann,

Ludwig-Maximilians-Universität

München, Germany

*Correspondence:

Claudia Pinelli

claudia.pinelli@unicampania.it

Received: 26 June 2017 Accepted: 07 August 2017

Published: 21 August 2017

Citation:

D'Aniello B, Semin GR, Scandurra A and Pinelli $C$ (2017) The Vomeronasal

Organ: A Neglected Organ.

Front. Neuroanat. 11:70.

doi: 10.3389/fnana.2017.00070 the VNO develops very early (Smith et al., 1997; Garrosa et al., 1998). The nerve fibers of the VNO extend together with a cluster of migrating gonadotropin releasing hormone ( $\mathrm{GnRH}$ )-secreting cells from the olfactory placode toward the brain (Wray, 2010). Subsequently, compared to other mammals the VNO of the adult human shows some signs of regression (Trotier et al., 2000; Bhatnagar and Smith, 2001; Trotier, 2011).

Endoscopic observations of humans show that it is possible to observe the vomeronasal cavities and ducts in the case of some individuals (Moran et al., 1991; Stensaas et al., 1991; Boehm and Gasser, 1993; Trotier and Døving, 1996; Trotier et al., 2000; Witt and Hummel, 2006; Stoyanov et al., 2016). In adult humans, the VNO is structurally a tube-shaped canal with a blind-ending opening into the nasal cavity (Bhatnagar and Smith, 2001). According to Bhatnagar and Smith (2001), the presence and the location of the VNO is clearly demonstrated by serial sectioning of the nasal septum convincingly. However, it lacks sensory neurons and nerve fibers (Trotier et al., 2000; Trotier, 2011; Stoyanov et al., 2016). The size and shape of the VNO exhibits considerable variability in humans.

The functional aspects of the human vomeronasal organ are the subject of debate. In humans, the genes coding for vomeronasal receptor proteins and the specific ionic channels involved in the transduction process identified in species with a functional VNO have mutated and are non-functional. Furthermore, in the case of humans, no accessory olfactory bulbs (AOB) that receive information from the vomeronasal receptor cells are present. Thus, the sensory function of the vomeronasal is considered to be non-operative (see Dulac and Torello, 2003). Notably, it has recently been shown that there are morphological connections of the VNO cells with the underlying 
capillaries. These, along with the expression of calcium-binding protein in part of these cells, suggest a potential endocrine activity (Wessels et al., 2014). If so, we would have the first evidence of an alternative function than the usually assumed pheromone sensing one for the VNO. An endocrine function of the VNO has not been reported for any other organism and could possibly account for the enigmatic effects of pheromones on human behavior ensuing upon the stimulation of the adult human VNO despite the absence of olfactory sensory neurons (Monti-Bloch et al., 1998).

In most land vertebrates, the associated central nervous structures of the VNO consist of the AOB and the vomeronasal amygdala. The connections between them are established by the corresponding nerves and tracts (Salazar et al., 2016). The glands associated with the VNO secrete fluids that fill this discrete structure (Meredith, 1994; Rehorek et al., 2000; Nowack and Wöhrmann -Repenning, 2009). The specific openings under the palatine vault and the ducts that break into the nasal canal permit the entrance of chemosignals to the VNO. Unlike the cilia of the olfactory receptors to the main olfactory system (MOS) the receptor neurons of the VNO sensory epithelium possess apical microvilli (Stensaas et al., 1991; Døving and Trotier, 1998). Notably, there are also documented cases of ciliated vomeronasal receptor cells (Adams and Weikamp, 1984; Saint Girons and Zylberberg, 1992). The axons of the VNO merge together, forming vomeronasal nerves which end in the AOBs (Barber and Raisman, 1974), within vomeronasal glomeruli.

Even though there are many studies addressing the functional, ontogenetic and phylogenetic aspects of VNO, the literature reveals little agreement. Jacobson's study (1811) underlined that the VNO appeared when the tetrapods conquered the lands. It was logical to link VNO function with the perception of airborne odors (Bertmar, 1981). However, Broman (1920) observed that liquids filled the VNO, which hold for water born substances. For this reason, he hypothesized that the fish main olfactory mucosa was homolog to the VNO of vertebrates, whereas the MOS was a new acquisition of tetrapods. This observation was recently supported by a review in cartilaginous fishes (Chondrichthyes), claiming that the sense of smell could primarily (or completely) rely on the vomeronasal sense (Ferrando and Gallus, 2013). However, this hypothesis seems flawed since the projections of the olfactory bulbs in fish and tetrapods are similar. On one hand, the Bertmar hypothesis is unsustainable given the presence of vomeronasal related structures in larval and the adult aquatic amphibians (Eisthen, 1997). On the other hand, there

\section{REFERENCES}

Adair, J. S. (1964). The olfactory bulb and related nuclei of the sturgeon (Scaphirhynchus platorhynchus). Ala J. Med. Sci. 35, 386-398.

Adams, D. R., and Weikamp, M. D. (1984). The canine vomeronasal organ. J. Anat. $138,771-787$.

Barber, P. C., and Raisman, G. (1974). An autoradiographic investigation of the projection of the vomeronasal organ to the accessory olfactory bulb in the mouse. Brain Res. 81, 21-30. doi: 10.1016/0006-8993(74)90476-4

Bertmar, G. (1981). Evolution of vomeronasal organs in vertebrates. Evolution 35, 359-366. doi: 10.1111/j.1558-5646.1981.tb04893.x is increasing evidence reporting the presence of vomeronasal related structures, together with the MOS, in early gnathostomes. In the rat fish (Chimaera, Chondrichthyes), AOBs are described as associated with the dorsal and ventral parts of each main olfactory bulb (Faucette, 1969). In some lungfishes (Dipnoa) species, an AOB has been reported (Rudebeck, 1944; Schnitzlein and Crosby, 1967), with separate vomeronasal and olfactory nerves (Schnitzlein and Crosby, 1967; González et al., 2010). In the ray-finned fishes (Actinopterygii), such as sturgeon (Scaphirhynchus platorhynchus; Adair, 1964) and the paddlefish (Polyodon spathula; Story, 1964) the AOB has been identified as a dorsomedial part of the main olfactory bulb. Finally, a part of the main olfactory bulbs of Amia calva, a living fossil, has been recognized as an AOB (Schnitzlein, 1964). Neither in the chondrichthyans, nor in the osteichthyans a clear VNO has been identified. However, recently a potential vomeronasal organ homolog in form of accessory epithelial crypts within the nasal cavities of dipnoans showing multisynaptic connectivity reminiscent of the tetrapod AOS has been reported (González et al., 2010; Nakamuta et al., 2012; Wittmer and Nowack, 2017). Also, special sensory cells (some microvillous and all crypt cells) with connections supportive of an accessory olfactory or vomeronasal system in teleosts (Biechl et al., 2017) have been described. Thus, it is possible that the VNO may be present in teleosts in an unsegregated form, with the sensory neurons of the VNO mixed with those of the MOS. This hypothesis is supported by the observation that the fish's olfactory mucosa contains both ciliated olfactory sensory neurons (which are typical for the tetrapod main olfactory epithelium) and microvillous olfactory sensory neurons (which are characteristic of VNO in tetrapods) (Hansen et al., 2003, 2004), as well as crypt and Kappe cells which may also contribute to the AOS (Biechl et al., 2017).

Different from fish species, the presence of a VNO has been largely recognized in tetrapods, although, in the proteids (Amphibia, Apoda), in birds and in some mammals (for example cetacea) it is absent. From this overview, it appears that the VNO or vomeronasal equivalents in vertebrates are more widespread than previously believed and the cases of absence in tetrapods are probably secondary adaptive conditions.

\section{AUTHOR CONTRIBUTIONS}

All authors listed have made a substantial, direct and intellectual contribution to the work, and approved it for publication. 
Boehm, N., and Gasser, B. (1993). Sensory receptor-like cells in the human foetal vomeronasal organ. Neuroreport 4, 867-870. doi: 10.1097/00001756-199307000-00007

Broman, I. (1920). Das Organon vomero-nasale Jacobsoni - ein Wassergeruchsorgan! Ergebn. Anat. EntwGesch 58, 143-191.

Døving, K. B., and Trotier, D. (1998). Structure and function of the vomeronasal organ. J. Exp. Biol. 201, 2913-2925.

Dulac, C., and Torello, A. T. (2003). Molecular detection of pheromone signals in mammals: from genes to behaviour. Nat. Rev. Neurosci. 4, 551-562. doi: $10.1038 / \mathrm{nrn} 1140$

Eisthen, H. L. (1997). Evolution of vertebrate olfactory systems. Brain Behav. Evol. 50, 222-233. doi: 10.1159/000113336

Faucette, J. R. (1969). The accessory olfactory bulbs and the lateral telencephalic wall of the rat-fish, Chimaera. J. Comp. Neurol. 137, 407-431. doi: 10.1002/cne. 901370403

Ferrando, S., and Gallus, L. (2013). Is the olfactory system of cartilaginous fishes a vomeronasal system? Front. Neuroanat. 7:37. doi: 10.3389/fnana.2013. 00037

Garrosa, M., Gayoso, M. J., and Esteban, F. J. (1998). Prenatal development of the mammalian vomeronasal organ. Microsc. Res. Tech. 41, 456-470. doi: 10.1002/(SICI)1097-0029(19980615)41:6<456::AID-JEMT2>3.0.CO;2-L

González, A., Morona, R., López, J. M., Moreno, N., and Northcutt, R. G. (2010). Lungfishes, like tetrapods, possess a vomeronasal system. Front. Neuroanat. 1:4. doi: 10.3389/fnana.2010.00130

Hansen, A., Anderson, K. T., and Finger, T. E. (2004). Differential distribution of olfactory receptor neurons in goldfish: structural and molecular correlates. J. Comp. Neurol. 477, 347-359. doi: 10.1002/cne.20202

Hansen, A., Rolen, S. H., Anderson, K., Morita, Y., Caprio, J., and Finger, T. E. (2003). Correlation between olfactory receptor cell type and function in the channel catfish. J. Neurosci. 23, 9328-9339.

Jacobson, L. (1811). Description anatomique d'un organe observe dans le mammiferes. Ann. Mus. Hist. Natl. 18, 412-424.

Kölliker, A. (1877). Über die Jacobson'schen Organe des Menschen. Leipzig: Wilhelm Engelmann. $11 \mathrm{p}+2$ plates with explanation of figures.

McGann, J. P. (2017). Poor human olfaction is a 19th-century myth. Science 356, 6338. doi: 10.1126/science.aam 7263

Meredith, M. (1994). Chronic recording of vomeronasal pump activation in awake behaving hamsters. Physiol. Behav. 56, 345-354. doi: 10.1016/0031-9384(94)90205-4

Monti-Bloch, L., Jennings-White, C., and Berliner, D. L. (1998). The human vomeronasal system: a review. Ann. N.Y. Acad. Sci. 855, 373-389. doi: 10.1111/j.1749-6632.1998.tb10595.x

Moran, D. T., Jafek, B. W., and Rowley, J. C. III. (1991). The vomeronasal (Jacobson's) organ in man: ultrastructure and frequency of occurrence. J. Steroid Biochem. Mol. Biol. 39, 545-552. doi: 10.1016/0960-0760(91) 90251-Y

Nakamuta, S., Nakamuta, N., Taniguchi, K., and Taniguchi, K. (2012). Histological and ultrastructural characteristics of the primordial vomeronasal organ in lungfish. Anat. Rec. 295, 481-491. doi: 10.1002/ar. 22415

Nowack, C., and Wöhrmann -Repenning, A. (2009). New anatomical analyses suggest a pumping mechanism for the vomeronasal organ in anurans. Copeia 1, 6. doi: $10.1643 / \mathrm{CH}-07-267$

Potiquet, M. (1891). Le canal de Jacobson. Rev. Laryngol. 2, 737-753.

Rehorek, S. J., Firth, B. T., and Hutchinson, M. N. (2000). The structure of the nasal chemosensory system in squamate reptiles. 2 . Lubricatory capacity of the vomeronasal organ. J. Biosci. 25, 181-190.

Rudebeck, B. (1944). Does an accessory olfactory bulb exist in dipnoi? Acta Zool. 25, 89-96. doi: 10.1111/j.1463-6395.1944.tb00348.x

Ruysch, F. (1703). Thesaurus Anatomicus Tertius. Amstelaedami: Joannen Wolters. p. 48-49, 70; Plate IV. Fig. 5. (see English translation by Bhatnagar and Reid, 1996).

Ruysch, F. (1724). Thesaurus Anatomicus, Vol. 3. Amsterdam: Waesberg J.
Saint Girons, H., and Zylberberg, L. (1992). Histologie comparée des glandes céphaliques exocrines et des fosses nasales des Lissamphibia. II. Épitheliums des fosses nasales. Ann. Sci. Nat. Zool. (Paris) 13, 121-145.

Salazar, I., Barrios, A. W., and SáNchez-Quinteiro, P. (2016). Revisiting the vomeronasal system from an integrated perspective. Anat. Rec. 299, 1488-1491. doi: $10.1002 /$ ar. 23470

Schnitzlein, H. N. (1964). Correlation of habit and structure in the fish brain. Am. Zoologist 4, 21-32.

Schnitzlein, H. N., and Crosby, E. C. (1967). The telencephalon of the lungfish, Protopterus. J. Hirnforsch 9, 105-149.

Smith, T. D., Siegel, M. I., and Bhatnagar, K. P. (2001). Reappraisal of the vomeronasal system of catarrhine primates: ontogeny, morphology, functionality, and persisting questions. Anat. Rec. 265, 176-192. doi: $10.1002 / a r .1152$

Smith, T. D., Siegel, M. I., Mooney, M. P., Burdi, A. R., Burrows, A. M., and Todhunter, J. S. (1997). Prenatal growth of the human vomeronasal organ. Anat. Rec. 248, 447-455. doi: 10.1002/(SICI)1097-0185(199707)248:3<447::AID-AR18>3.0.CO;2-P

Spehr, M., Spehr, J., Ukhanov, K., Kelliher, K. R., Leinders-Zufall, T., and Zufall, F. (2006). Parallel processing of social signals by the mammalian main and accessory olfactory systems. Cell Mol. Life Sci. 63, 1476-1484. doi: 10.1007/s00018-006-6109-4

Stensaas, L. J., Lavker, R. M., Monti-Bloch, L., Grosser, B. I., and Berliner, D. L. (1991). Ultrastructure of the human vomeronasal organ. J. Steroid Biochem. Mol. Biol. 39, 553-560. doi: 10.1016/0960-0760(91)90252-Z

Story, H. (1964). The olfactory bulbar formation and related nuclei of the paddlefish (Polyodon spathula). J. Comp. Neurol. 123, 285-297. doi: $10.1002 / \mathrm{cne} .901230210$

Stoyanov, G., Moneva, K., Sapundzhiev, N., and Tonchev, A. B.,(2016). The vomeronasal organ - incidence in a Bulgarian population. J. Laryngol. Otol. 130, 344-347. doi: 10.1017/S0022215116000189

Trotier, D. (2011). Vomeronasal organ and human pheromones. Eur. Ann. Otorhinolaryngol. Head Neck Dis. 128, 184-190. doi: 10.1016/j.anorl.2010.11.008

Trotier, D., and Døving, K. B. (1996). Functional role of receptor neurons in encoding olfactory information. J. Neurobiol. 30, 58-66. doi: 10.1002/(SICI)1097-4695(199605)30:1 < 58::AID-NEU6>3.0.CO;2-F

Trotier, D., Eloit, C., Wassef, M., Talmain, G., Bensimon, J. L., Døving, K. B., et al. (2000). The vomeronasal cavity in adult humans. Chem. Senses 25, 369-380. doi: $10.1093 /$ chemse/25.4.369

Wessels, Q., Hoogland, P. V., and Vorster, W. (2014). Anatomical evidence for an endocrine activity of the vomeronasal organ in humans. Clin. Anat. 27, 856-860. doi: $10.1002 / \mathrm{ca} .22382$

Witt, M., and Hummel, T. (2006). Vomeronasal versus olfactory epithelium: is there a cellular basis for human vomeronasal perception? Int. Rev. Cytol. 248, 209-259. doi: 10.1016/S0074-7696(06)48004-9

Wittmer, C., and Nowack, C. (2017). Epithelial crypts: a complex and enigmatic olfactory organ in African and South American lungfish (Lepidosireniformes, Dipnoi). J. Morph. 278, 791-800. doi: 10.1002/jmor.20673

Wray, S. (2010). From nose to brain: development of gonadotrophinreleasing $\begin{array}{lllll}\text { hormone-1 neurones. J. Neuroendocrinol. 22, 743-753. } & \text { J. }\end{array}$ doi: $10.1111 / j .1365-2826.2010 .02034 . x$

Conflict of Interest Statement: The authors declare that the research was conducted in the absence of any commercial or financial relationships that could be construed as a potential conflict of interest.

Copyright () 2017 D'Aniello, Semin, Scandurra and Pinelli. This is an open-access article distributed under the terms of the Creative Commons Attribution License (CC $B Y)$. The use, distribution or reproduction in other forums is permitted, provided the original author(s) or licensor are credited and that the original publication in this journal is cited, in accordance with accepted academic practice. No use, distribution or reproduction is permitted which does not comply with these terms. 